\title{
ANALISIS DAN REKAYASA PROSES BISNIS PADA BAGIAN LAYANAN AKADEMIK DI SEKRETARIAT FAKULTAS SAINS DAN TEKNOLOGI UNIVERSITAS MA CHUNG
}

\author{
Andy Lieman Chandra*), Yuswono Hadi \\ Jurusan Teknik Industri, Fakultas Sains dan Teknologi, Universitas Ma Chung \\ Jl. Villa Puncak Tidar N-01, Malang, 65151
}

(Received: May 29, 2017/ Accepted: September 22, 2017)

\begin{abstract}
Abstrak
Sekretariat Fakultas Sains dan Teknologi Universitas Ma Chung merupakan fakultas dimana Penulis melakukan penelitian. Tujuan dari penelitian ini adalah untuk menganalisis proses bisnis yang ada di Sekretariat Fakultas Sains dan Teknologi Universitas Ma Chung berdasarkan dari hasil wawancara dengan beberapa stakeholder yang memiliki kebutuhan ataupun keluhan terhadap setiap proses bisnis yang berjalan, mengidentifikasi permasalahan dari proses bisnis yang kurang efisien dan membuat usulan perbaikan untuk setiap proses bisnis dengan menggunakan pendekatan ilmu Business Process Reengineering (BPR). Penulis juga menggunakan metode analisis nilai tambah pada penelitian ini. Tujuan dari penggunaan metode analisis nilai tambah adalah untuk mengkategorikan langkah maupun elemen kerja ke dalam tiga kategori, yakni value adding, business value adding dan non value adding. Pengaktegorisasian tersebut bertujuan untuk menghilangkan langkah maupun elemen kerja yang termasuk kedalam non value adding dan meminimalkan langkah maupun elemen kerja yang termasuk kedalam business value adding. Penulis mengidentikasi permasalahan setiap proses bisnis dengan menggunakan diagram sebab akibat. Diagram sebab akibat dapat menggambarkan dengan jelas mengenai permasalahan dengan faktor-faktor penyebab yang memengaruhi permasalahan di setiap proses bisnis. Hasil dari penelitian ini adalah pendesainan ulang setiap proses bisnis menurut kebutuhan dan keluhan dari stakeholder dan setiap proses bisnis di Sekretariat Fakultas Sains dan Teknologi didokumentasikan dalam bentuk standard operating procedure (SOP).
\end{abstract}

Kata kunci: Business Process Reengineering, Rekayasa Proses Bisnis, Analisis Nilai Tambah, Standard Operating Procedure dan Diagram Sebab Akibat.

\begin{abstract}
Secretariat of Faculty of Science and Technology Ma Chung University is a place where the author conducts research. The purposes of this research are to analyze business processes in Secretariat of Faculty of Science and Technology Ma Chung University based on interview results with some stakeholders who have needs or complaints with ongoing business processes, identify problems of less efficient business processes and make proposed improvements for each business process using the Business Process Reengineering approach. Author also uses value added analysis method on this research. The purpose of using value added analysis method is to categorize steps or tasks in every business process into three categories: value adding, business value adding and non value adding. The categorizations aim to eliminate steps or tasks included into non value adding and minimize steps or tasks included into business value adding. Author identifies problems of each business process by using cause and effect diagram. Cause and effect diagram can clearly illustrate the problems with the underlying factors that affect the problem in each business process. The results of this research are redesigning every business processes according to the interview results with stakeholders about their needs and complaints and also every business process in Secretariat of Faculty of Science and Technology are documented in the form of standard operating procedure.
\end{abstract}

Keywords: Business Process Reengineering, Value Added Analysis, Standard Operating Procedure and Cause and Effect Diagram.

\footnotetext{
${ }^{*}$ Penulis Korespondensi.

email: 411310005@student.machung.ac.id
} 


\section{Pendahuluan}

Perkembangan teknologi di bidang komunikasi mengakibatkan pertukaran informasi dituntut untuk menjadi lebih efisien. Menurut Losee (1997) informasi adalah satu atau lebih pernyataan bersifat fakta yang disampaikan oleh pengirim kepada penerima dengan tujuan untuk memberi manfaat yang berarti bagi penerimanya, sehingga informasi menjadi lebih berkualitas. Menurut Wang dan Strong (1996) suatu informasi dapat dikatakan berkualitas apabila memiliki empat kriteria utama, yakni informasi yang disampaikan harus akurat atau tidak menimbulkan bias bagi penerimanya, informasi yang disampaikan harus tepat waktu atau tidak boleh terlambat, informasi yang disampaikan harus memiliki keterkaitan dengan permasalahan yang ada dan informasi yang disampaikan harus lengkap dalam kuantitas yang sesuai dengan kebutuhan.

Penyampaian informasi secara berkualitas harus mutlak dimiliki oleh sebuah perusahaan atau instansi. Penyampaian informasi secara berkualitas dapat meminimalisir biaya atau tenaga yang dikeluarkan, sehingga kualitas pelayanan perusahaan dapat meningkat. Informasi yang berkualitas dapat dicapai apabila seluruh struktur organisasi perusahaan atau instansi telah memiliki koordinasi yang baik. Koordinasi yang baik antara departemen-departemen di dalam struktur organisasi sangat mutlak dibutuhkan. Hal tersebut dikarenakan dalam suatu departemen tentu memiliki beberapa bisnis proses yang saling berkaitan antara satu dengan yang lainnya.

Bisnis proses merupakan beberapa aktivitas yang memerlukan masukan dan terdapat pada setiap departemen dalam struktur organisasi yang bertujuan untuk menghasilkan luaran yang diinginkan oleh perusahaan tersebut (Magal dan Word, 2012). Banyak perusahaan atau instansi menyadari mengenai pentingnya pengoptimalan proses bisnis pada seluruh departemen di perusahaan atau unstansi tersebut. Proses bisnis yang telah berjalan secara optimal dapat mengakibatkan penurunan biaya yang harus dikeluarkan serta peningkatan kualitas informasi yang disampaikan oleh seluruh departemen yang terdapat di perusahaan.

Universitas Ma Chung merupakan instansi pendidikan milik swasta yang terletak di kota Malang. Universitas Ma Chung memiliki beberapa departemen yang bertugas untuk melayani kebutuhan mahasiswa dan dosen. Salah satu departemen yang sering berhubungan dengan kegiatan mahasiswa dan dosen adalah Sekretariat Fakultas. Terdapat tiga macam Sekretariat Fakultas yang ada di Universitas Ma Chung, yakni Sekretariat Fakultas Sains dan Teknologi, Sekretariat Fakultas Bahasa dan Seni, dan Fakultas Ekonomi dan Bisnis. Sekretariat Fakultas harus dituntut untuk dapat menyediakan informasi yang berkualitas bagi mahasiswa serta dosen.

Menurut Bapak Rudy Setiawan., S.Si., M.T. selaku Dekan Fakultas Sains dan Teknologi Universitas Ma Chung, terkadang Sekretariat Fakultas khususnya
Sekretariat Fakultas Sains dan Teknologi menyampaikan informasi secara kurang akurat. Beberapa contoh ketidakuratan informasi yang terdapat pada Sekretariat Fakultas Sains dan Teknologi adalah pengaturan jadwal mengajar yang kurang terstruktur dengan baik, sering terjadinya salah paham mengenai prosedur penyerahan maupun pengembalian soal ujian akhir semester, dan lain sebagainya. Hal tersebut dapat mengakibatkan seluruh aktivitas kegiatan yang berhubungan dengan akademik menjadi terhambat. Oleh sebab itu pendekatan ilmu rekayasa bisnis proses perlu dilakukan pada penelitian ini untuk meningkatkan kualitas informasi yang disampaikan oleh Sekretariat Fakultas Sains dan Teknologi Universitas Ma Chung.

\section{Metodologi Penelitian \\ Kualitas Informasi}

Menurut Sutabri (2005) terdapat beberapa persyaratan yang harus dipenuhi agar informasi dapat dikatakan berkualitas. Berikut ini merupakan penjelasan dari persyaratan-persyaratan tersebut.

1. Relevan (Relevance)

Informasi yang disampaikan harus memiliki hubungan terkait dengan permasalahan yang ada dan dapat memberikan manfaat bagi penerima informasi, sehingga visi, misi, dan tujuan dari perusahaan atau instansi dapat tercapai dengan baik.

2. Tepat Waktu

Informasi yang disampaikan oleh seluruh departemen dalam perusahaan atau instansi harus tepat waktu, sehingga saat perusahaan membutuhkannya informasi juga telah tersedia dengan baik.

3. Akurat (Accuracy)

Informasi yang disampaikan haruslah bersih dari kesalahan maupun kekeliruan, sehingga informasi harus tepat dan jelas dalam mencerminkan makna yang terkandung pada data.

4. Luas dan lengkap

Informasi yang disampaikan harus memiliki sifat kelengkapan yang tinggi, sehingga hal tersebut tidak menimbulkan bias bagi penerimanya.

\section{Rekayasa Proses Bisnis}

Rekayasa proses bisnis merupakan pendekatan ilmu yang sangat penting bagi suatu perusahaan dalam meningkatkan efisiensi dan efektivitas kerjanya. Menurut Mohapatra (2013) terdapat enam kerangka ataupun langkah dasar yang mendasari dari pendekatan ilmu rekayasa proses bisnis, yakni :

1. Mengembangkan visi, misi dan tujuan dari perusahaan.

2. Mengidentifikasi proses yang akan didesain ulang.

3. Memahami dan mengukur proses bisnis yang ada sekarang.

4. Mengidentifikasi pengaruh dari teknologi informasi.

5. Mendesain ulang ataupun membuat prototipe dari proses bisnis yang baru. 
6. Melakukan implementasi perbaikan.

\section{Analisis Proses Kualitatif}

Analisis proses kualitatif merupakan suatu seni dalam melakukan analisis proses. Teknik dasar dalam melakukan analisis proses kualitatif adalah dengan mengidentifikasi maupun menganalisis bagian yang menjadi titik lemah dari suatu proses (Dumas, dkk. 2013). Metode analisis nilai tambah merupakan salah satu metode yang terdapat pada analisis proses secara kualitatif. Secara umum, analisis nilai tambah adalah suatu teknik dimana seorang analis mengupas lebih lanjut mengenai model dari suatu proses, mengekstraksi setiap langkah dari suatu proses dan mengelompokkan elemen kerja dari setiap langkah menjadi salah satu dari tiga kategori, yakni value adding (VA), business value adding (BVA) dan non value adding (NVA).

Value adding merupakan aktivitas yang sangat penting untuk dilakukan dalam suatu proses dan dapat meningkatkan kepuasan pelanggan, sehingga pelanggan akan rela membayar demi aktivitas tersebut. Business value adding merupakan langkah yang memang perlu dilakukan oleh perusahaan atau instansi, tetapi tidak memberikan kepuasaan atau manfaat bagi pelanggan. Non value adding merupakan langkah yang memang tidak perlu untuk dilakukan oleh perusahaan atau instansi dan juga tidak memberikan manfaat atau meningkatkan kepuasan kepada pelanggan (Dumas, dkk. 2013).

\section{Metode Penelitian}

\section{Identifikasi Masalah}

Pada Sekretariat Fakultas Sains dan Teknologi seringkali terjadi kesalahan dalam penyampaian informasi. Kesalahan penyampaian informasi tersebut mengakibatkan informasi yang diberikan menjadi tidak akurat, tidak relevan, tidak lengkap dan tidak bisa tepat waktu. Oleh karena itu diperlukan adanya perbaikan secara fundamental dan menyeluruh pada Sekretariat Fakultas Sains dan Teknologi Universitas Ma Chung, sehingga dapat meningkatkan kualitas informasi yang disampaikan.

\section{Tahap Pengolahan Data}

Data yang diambil merupakan data mengenai kebutuhan dan keluhan yang dirasakan oleh stakeholder terhadap proses bisnis yang berjalan di Sekretariat Fakultas Sains dan Teknologi saat ini serta melalui pengamatan langsung. Data kebutuhan dan keluhan data melalui pengamatan langsung tersebut akan digunakan sebagai alat analisis dan dasar pengkategorian setiap elemen kerja maupun langkah kerja dengan menggunakan metode analisis nilai tambah. Hasil analisis dan pengaktegorian tersebut digunakan sebagai dasar dalam melakukan pendesainan ulang setiap proses bisnis.

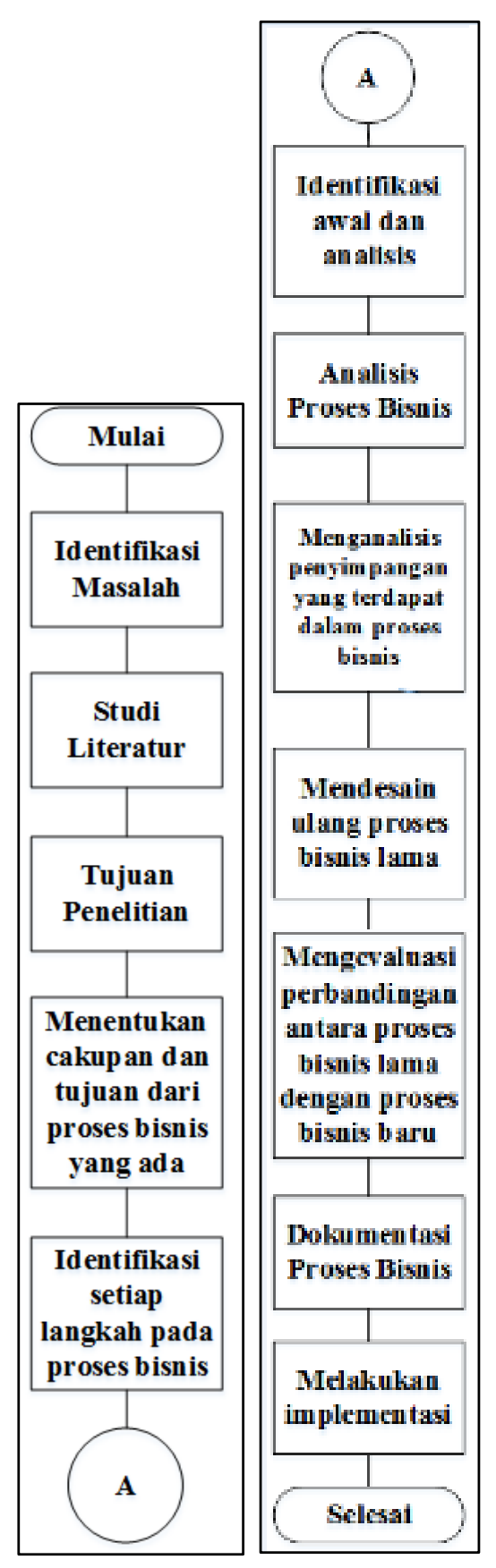

Gambar 1. Diagram Alir Prosedur Penelitian

\section{Hasil dan Pembahasan}

Pada Sekretariat Fakultas Sains dan Teknologi terdapat standard operating procedure yang dulu sudah dibuat, namun tidak didokumentasikan dengan baik. Hal tersebut mengakibatkan pekerjaan yang dijalankan tidak efektif dan efisien.

Pengambilan data dilakukan dengan metode wawancara kepada beberapa stakeholder terkait mengenai proses bisnis yang ada pada bagian layanan akademik. Hasil wawancara mengenai kebutuhan dan keluhan dari beberapa stakeholder terhadap setiap proses bisnis yang ada di Sekretariat Fakultas pada bagian layanan akademik akan dikelompokkan kedalam empat dimensi kualitas informasi, yakni akurat, lengkap 
dan memadai, tepat waktu dan relevansi.

Pada jurnal ini akan dibahas mengenai salah satu contoh proses bisnis pada bagian layanan akademik, yakni proses pembuatan SK Mengajar mulai dari analisis kebutuhan dan keluhan dari stakeholder, analisis proses bisnis terdahulu, analisis elemen kerja dan usulan perbaikan yang akan didokumentasikan dalam bentuk standard operating procedure.

SK Mengajar merupakan surat keterangan mengajar yang harus ada di awal perkuliahan. Surat tersebut digunakan oleh beberapa dosen sebagai pedoman dalam melakukan proses belajar mengajar. Tabel 1. menunjukkan hasil wawancara akan kebutuhan maupun keluhan dari beberapa stakeholder mengenai proses pembuatan SK Mengajar.

Setelah dilakukan analisis kebutuhan dan keluhan dari beberapa stakeholder mengenai proses bisnis pembuatan SK Mengajar, maka selanjutnya dilakukan analisis proses bisnis dengan membuat bagan alir terdahulu dari proses bisnis pembuatan SK Mengajar.

Langkah-langkah dari pembuatan SK Mengajar dapat dilihat pada Gambar 2.

Tabel 1. Kebutuhan dan Keluhan Stakeholder Mengenai Pembuatan SK Mengajar

\begin{tabular}{|c|c|}
\hline $\begin{array}{l}\text { Dimensi Kualitas } \\
\text { Informasi }\end{array}$ & Kebutuhan dan Keluhan \\
\hline Akurat & $\begin{array}{l}\text { Menurut wawancara yang telah dilakukan terhadap beberapa stakeholder diketahui } \\
\text { bahwa form-form yang berkaitan dengan pembuatan SK Mengajar yang diberikan oleh } \\
\text { beberapa Kaprodi belum memiliki standar yang jelas. Selain itu dari Sekretariat Fakultas } \\
\text { sendiri tidak memberikan format yang jelas kepada beberapa Kaprodi, sehingga } \\
\text { menyebabkan SK Mengajar sering mengalami revisi. }\end{array}$ \\
\hline Lengkap dan memadai & $\begin{array}{l}\text { Menurut wawancara yang telah dilakukan terhadap beberapa stakeholder diketahui bahwa } \\
\text { form-form yang diberikan kepada Sekretariat Fakultas belum lengkap dan memadai, } \\
\text { sehingga pembuatan SK Mengajar sering salah. }\end{array}$ \\
\hline Relevansi & $\begin{array}{l}\text { Menurut wawancara yang telah dilakukan terhadap beberapa stakeholder SK Mengajar } \\
\text { yang telah dibuat belum dapat memberikan manfaat secara maksimal terhadap penerima } \\
\text { informasi, karena sering mengalami revisi. }\end{array}$ \\
\hline Tepat waktu (Timeliness) & $\begin{array}{l}\text { Menurut wawancara yang telah dilakukan terhadap beberapa stakeholder, SK Mengajar } \\
\text { yang dibuat sering terlambat karena belum ada saat awal perkuliahan dimulai. }\end{array}$ \\
\hline
\end{tabular}

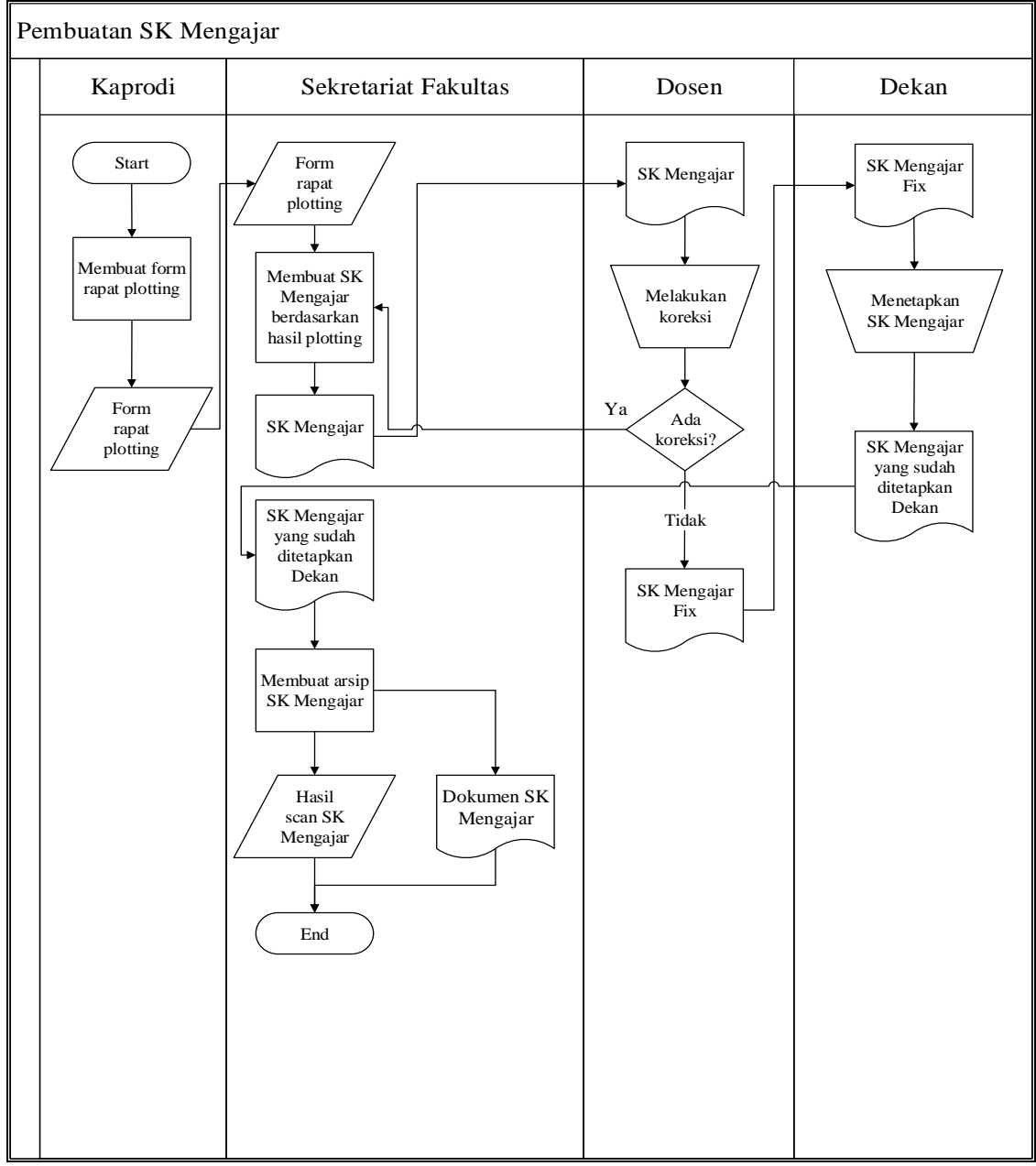

Gambar 2. Bagan Alir Terdahulu Pembuatan SK Mengajar 
Langkah-langkah maupun elemen kerja pada proses bisnis pembuatan SK Mengajar selanjutnya dianalisis menggunakan metode analisis nilai tambah ke dalam tiga kategori, yakni value adding, business value adding dan non value adding. Pengkategorian tersebut bertujuan untuk memudahkan penghilangan elemen kerja yang dianggap tidak perlu dan harus diminimalkan. Tabel 2. merupakan pembagian elemen kerja pada proses pembuatan SK Mengajar.
Berdasarkan dari tabel analisis penggolongan elemen kerja pembuatan SK Mengajar, dapat diketahui bahwa terdapat beberapa elemen kerja yang harus diganti atau dihilangkan dengan tujuan untuk meningkatkan efisiensi dan efektivitas dari proses pembuatan SK Mengajar. Berikut ini merupakan tabel permasalahan dan perbaikan dari pembuatan SK Mengajar.

Tabel 2. Penggolongan Elemen Kerja Proses Pembuatan SK Mengajar

\begin{tabular}{|c|c|c|c|}
\hline Langkah & Elemen Kerja & Keterangan & Kategori \\
\hline \multirow[t]{2}{*}{ Pertama } & Pertama & $\begin{array}{l}\text { Kaprodi membuat form untuk plotting mata kuliah semester } \\
\text { berikutnya }\end{array}$ & Non value adding \\
\hline & Kedua & Kaprodi mengirim hasil form rapat plotting & Non value adding \\
\hline \multirow{4}{*}{ Kedua } & Pertama & $\begin{array}{l}\text { Sekretariat Fakultas menerima dan mengunduh form hasil rapat } \\
\text { plotting }\end{array}$ & Non value adding \\
\hline & Kedua & Sekretariat Fakultas membuat dokumen SK Mengajar & Value adding \\
\hline & Ketiga & $\begin{array}{l}\text { Sekretariat Fakultas melakukan verifikasi terhadap dosen yang } \\
\text { bersangkutan }\end{array}$ & Non value adding \\
\hline & Keempat & $\begin{array}{l}\text { Sekretariat Fakultas mengirim atau menyerahkan dokumen SK } \\
\text { Mengajar }\end{array}$ & Non value adding \\
\hline \multirow{3}{*}{ Ketiga } & Pertama & Dosen menerima dokumen SK Mengajar & Non value adding \\
\hline & Kedua & Dosen melakukan koreksi terhadap SK Mengajar yang dibuat & Business value adding \\
\hline & Ketiga & Sekretariat Fakultas melakukan revisi terhadap SK Mengajar & Business value adding \\
\hline \multirow{2}{*}{ Keempat } & Pertama & Sekretariat Fakultas mencetak dokumen SK Mengajar & Value adding \\
\hline & Kedua & Dekan menyetujui SK Mengajar & Value adding \\
\hline \multirow[b]{2}{*}{ Kelima } & Pertama & Sekretariat Fakultas membuat hasil scan SK Mengajar & Value adding \\
\hline & Kedua & $\begin{array}{l}\text { Sekretariat Fakultas membuat arsip dokumen SK Mengajar di } \\
\text { odner }\end{array}$ & Business value adding \\
\hline
\end{tabular}

\begin{tabular}{|c|c|c|c|c|}
\hline \multicolumn{5}{|c|}{ Semester 2} \\
\hline No. & Kode MK & Nama Mata Kuliah & SKS & Dosen \\
\hline 1 & Tl121 & Pengetabuan Lingkungan & 2 & PUR \\
\hline 2 & TI122 & Kalkulus II & 3 & RUDY \\
\hline 3 & TI123 & Statistik Iodustri I & 3 & YEW/SUN $(2+1)$ \\
\hline 4 & TI124 & Mengagabar Tekoik & 2 & TARA \\
\hline 5 & TI125 & Mekkaika Teknik & 3 & PUR \\
\hline 6 & MPK404 & Bahasa Inggris & 1 & \\
\hline 7 & MPK412 & Bahasa Tipoghoa & 1 & \\
\hline 8 & MPK401 & Pendidikan Agama & 3 & \\
\hline \multicolumn{3}{|r|}{ TOTAL } & 18 & \\
\hline \multicolumn{5}{|c|}{ Semester 4} \\
\hline No. & Kode MK & Nama Mata Kuliah & SKS & Dosen \\
\hline 1 & T1221 & Rengantac Ilonu Ekrosmi & 2 & IRFAN \\
\hline 2 & T1222 & $\begin{array}{l}\text { Rraktikum Erganomi \& Pecansangan Metode } \\
\text { Keria }\end{array}$ & 1 & SUN (tjidak Rerly kelas) \\
\hline 3 & T1223 & Pengendalian Kualitas Statistik & 3 & YEW $(2+1)$ \\
\hline 4 & T1224 & Psikglogi In dustri & 3 & PUR \\
\hline 5 & T1225 & Penelitian QRerasional II & 3 & TGO $(2+1)$ \\
\hline 6 & T1226 & $\begin{array}{l}\text { Rercancangan \& Rengembangan Rroduk } \\
\text { (+ Proxek) }\end{array}$ & 3 & SUN \\
\hline 7 & MPK404 & Pendidikan Kewarganergaraan & 3 & \\
\hline \multicolumn{3}{|r|}{ TOTAL } & 18 & \\
\hline \multicolumn{5}{|c|}{ Semester 6} \\
\hline No. & Kode MK & Nama Mata Kuliah & SKS & Dosen \\
\hline 1 & T1321 & Ekrosmi Teknik & 3 & YEW $(2+1)$ \\
\hline 2 & T1322 & Manajemen Proxelk (+ Praktikum) & 3 & TGO (2 kelas +2 Ole) \\
\hline 3 & T1323 & Analisis \& Recancangan Usaha & 3 & rwo \\
\hline 4 & T1324 & Enterprise Resources Planning (+ Eraktikyou) & 3 & \multirow{2}{*}{ rwO (2 kelas + 2 Ole $)$} \\
\hline 5 & T1325 & Simulasi sistem (+ Praktikum) & 3 & \\
\hline 6 & T1326 & $\begin{array}{l}\text { Rercesanaan \& Perancangan Fasilitas. } \\
\text { (+ Proxek) }\end{array}$ & 3 & $\begin{array}{l}\text { YWo }(2 \text { Ole }+2 \text { ole }) \\
\text { TGO }(2+1)\end{array}$ \\
\hline 7 & T1327 & Manaiemen Bantai Pasok & 3 & TGO \\
\hline \multicolumn{3}{|r|}{ TOTAL } & 21 & \\
\hline
\end{tabular}

Gambar 3. Form Rapat Plotting Prodi Teknik Industri 


\begin{tabular}{|c|c|c|c|c|c|}
\hline \multicolumn{6}{|c|}{ SEMESTER 2} \\
\hline NO & KODE MK & NAMA MATA KULIAH & DOSEN & KONDISI & RUANGAN \\
\hline 1 & DV 120 & Komunikasi Interpersonal & Dyestari Dyanutami, S.Sn.,M.Med.Kom & MANDIRI & ruang standar + kelas pagi \\
\hline 2 & DV 121 & Nirmana II + Praktikum & Tegar Andito, S.Sn., M.Sn. \& Khairani L. Imania, M.Ds & $\mathrm{TIM}$ & kaligrafi room + di atas jam 12.00 siang \\
\hline 3 & DV 122 & Ilustrasi II + Praktikum & Tegar Andito, S.Sn., M.Sn. & MANDIRI & kaligrafi room + hari beda dengan Nirmana + diatas 12.00 siang \\
\hline 4 & DV 124 & Teori Warna & Tegar Andito, S.Sn., M.Sn. & MANDIRI & kaligrafi room + hari sama dengan Nirmana + kelas pagi. \\
\hline 5 & DV 123 & Tipografi & Ayyub Anshari Sukmaraga, S.Sn., M.Ds. & MANDIRI & kaligrafi room + diatas jam 12 siang \\
\hline 6 & DV 125 & Menggambar Teknik & Khairani L. Imania, M.Ds & MANDIRI & kaligrafi room + di atas jam 12 siang \\
\hline \multicolumn{6}{|c|}{ SEMESTER 4} \\
\hline No & KODE MK & NAMA MATA KULIAH & \begin{tabular}{|c|} 
DOSEN \\
\end{tabular} & KONDISI & RUANGAN \\
\hline 1 & DV 220 & Branding \& Identitas & Sultan Arif Rahmadianto, S.Sn., M.Ds. & MANDIRI & ruang standar + kelas pagi \\
\hline 2 & DV 221 & Animasi + Praktikum & Tegar Andito, S.Sn., M.Sn. \& Khairani L. Imania, M.Ds & $\mathrm{TIM}$ & kaligrafi room $8 \times$ diawal + Lab. Siputri $8 \times$ di akhir + diatas jam 12 siang \\
\hline 3 & DV 222 & Metodologi Desain & Aditya Nirwana, S.Sn., M.Sn. & MANDIRI & ruang standar + kelas pagi \\
\hline 4 & DV 223 & Ilustrasi Musik Digital+ Praktikum & Didit Prasetyo Nugroho, S.Sn., M.Ds. + Moh.Fadil.W,S.Sn & TIM & Lab. Siputri \\
\hline 5 & DV 224 & Copywriting & Aditya Nirwana, S.Sn., M.Sn. & MANDIRI & ruang standar + kelas pagi \\
\hline \multicolumn{6}{|c|}{ MK PILIHAN KHUSUS ANGKATAN 2015} \\
\hline 1 & DV 500 & Fotografi Digital & Tegar Andito, S.Sn., M.Sn. & MANDIRI & Lab. Siputri \\
\hline 2 & DV 507 & Teori Periklanan & Ayyub Anshari Sukmaraga, S.Sn., M.Ds. & MANDIRI & ruang standar + kelas pagi \\
\hline 3 & DV 510 & Desain Komik & Didit Prasetyo Nugroho, S.Sn., M.Ds. & MANDIRI & kaligrafi room + diatas jam 12 siang \\
\hline 4 & DV 511 & Desain Web & Tegar Andito, S.Sn., M.Sn. \& Aditya Nirwana, S.Sn., M.Sn. & TIM & Lab. Siputri + diatas jam 12 siang \\
\hline 5 & DV 520 & Permodelan Karakter & Dimas Rifqi Novica, S.Sn.,M.Ds & MANDIRI & Lab. Siputri \\
\hline 6 & DV 523 & Desain Kemasan & Ayyub Anshari Sukmaraga, S.Sn., M.Ds. & MANDIRI & ruang standar + kelas pagi \\
\hline 7 & DV 526 & Mosaik & Didit Prasetyo Nugroho, S.Sn., M.Ds & MANDIRI & kaligrafi room \\
\hline
\end{tabular}

Gambar 4. Form Rapat Plotting Prodi Desain Komunikasi Visual

Hasil dari analisis nilai tambah setiap langkah maupun elemen kerja dan diagram sebab akibat akan digunakan dasar untuk dilakukannya perbaikan.
Tabel 3. merupakan tabel permasalahan dan perbaikan dari pembuatan SK Mengajar.

Tabel 3. Permasalahan dan Usulan Perbaikan dari Pembuatan SK Mengajar

\section{Permasalahan}

\begin{tabular}{ll}
\hline & \multicolumn{1}{c}{ Permasalahan } \\
\hline & $\begin{array}{l}\text { Kaprodi membuat form sendiri waktu rapat plotting } \\
\text { dilakukan, sehingga hal tersebut sering mengakibatkan }\end{array}$ \\
1 & $\begin{array}{l}\text { Sekretariat Fakultas harus melakukan verifikasi lagi kepada } \\
\text { dosen yang bersangkutan apabila form yang diberikan tidak } \\
\text { lengkap. }\end{array}$
\end{tabular}

Proses peralihan dokumen masih dilakukan dengan

2 menggunakan $e$-mail, sehingga hal tersebut membutuhkan waktu dan langkah yang sedikit agak lama dan panjang.

Proses koreksi SK Mengajar dan proses revisi SK Mengajar

3 yang dilakukan oleh Sekretariat Fakultas sering mengakibatkan proses pengeluaran SK Mengajar sering terlambat.

4 Adanya koreksi dari beberapa dosen mengakibatkan pembuatan SK Mengajar menjadi terhambat.
Pihak Sekretariat Fakultas membuat form standar yang sesuai dengan kebutuhan SK Mengajar.

Seharusnya proses peralihan dokumen dapat diminimalkan kembali menggunakan sistem sharing folder online yang terintegrasi antara pihak Kaprodi dengan Sekretariat Fakultas, sehingga data yang dibutuhkan selalu ada dan meminimalkan alasan kesulitan menemukan file tidak ditemukan karena pesan di kotak masuk yang banyak.

Proses koreksi dan proses revisi dapat diminimalkan dengan menggunakan form yang sudah terstandarisasi dari pihak Sekretariat Fakultas yang diberikan kepada Kaprodi. Adanya form yang terstandarisasi diharapkan dapat memudahkan proses pembuatan SK Mengajar.

Proses koreksi hanya ditujukan kepada Kaprodi, karena Kaprodi dianggap sudah mengetahui semua, sehingga proses koreksi hanya melibatkan satu pihak saja.

Pengarsipan dokumen-dokumen khususnya untuk dokumen SK, seperti dokumen SK Mengajar menggunakan odner yang berbeda.

5 dijadikan dalam satu odner, sehingga akan kesulitan sa hendak mencari dokumen SK Mengajar yang diperlukan. 


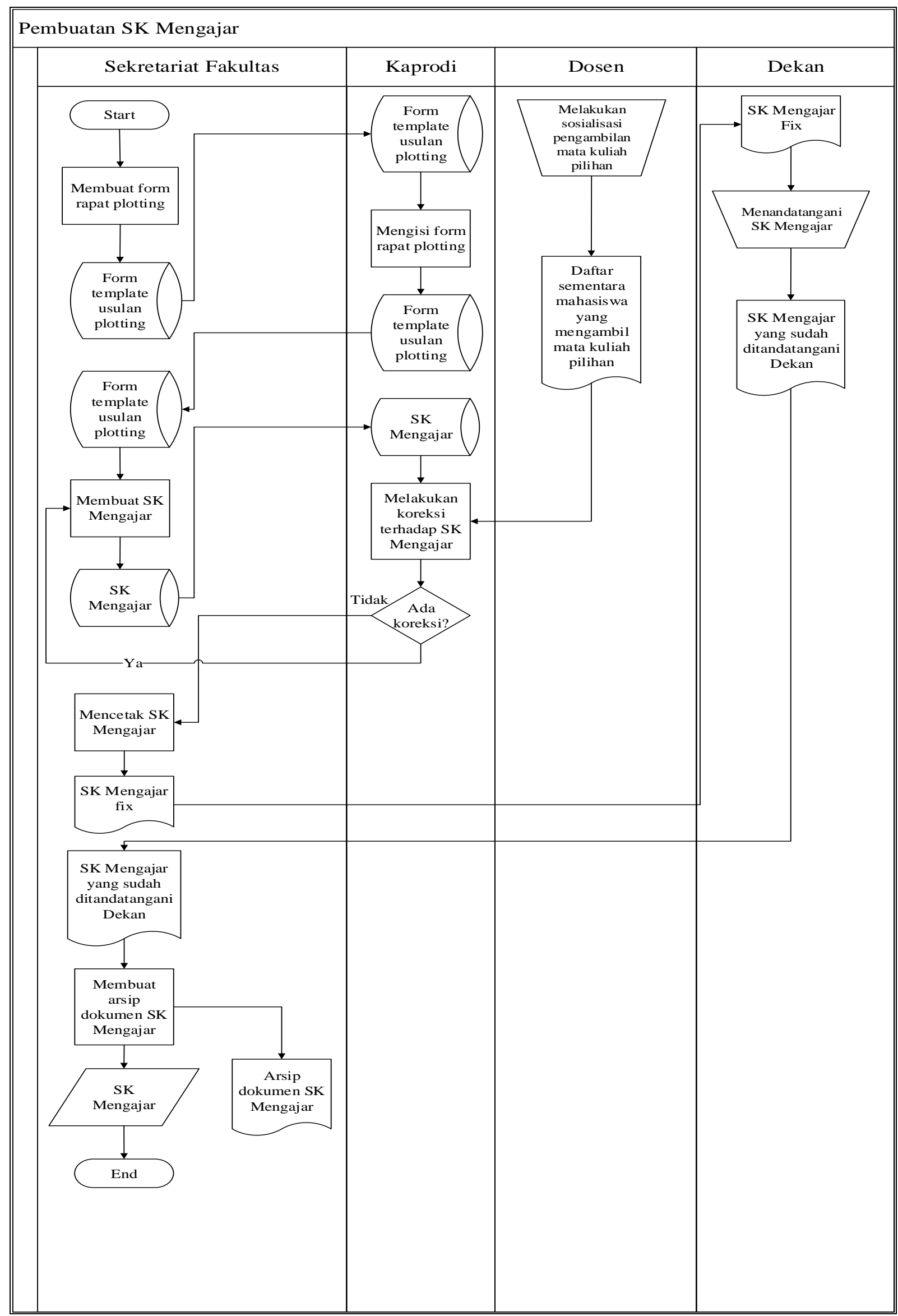

Gambar 5. Bagan Alir Usulan Proses Pembuatan SK Mengajar 
Berikut ini merupakan langkah-langkah dari usulan proses pembuatan SK Mengajar.

1. Sekretariat Fakultas mengkoordinir kegiatan rapat plotting dengan membuat form yang standar untuk kegiatan rapat plotting dan mengumumkan kegiatan rapat plotting.

2. Kaprodi melakukan kegiatan rapat plotting.

3. Dosen melakukan sosialisasi pengambilan mata kuliah pilihan kepada mahasiswa.

4. Sekretariat Fakultas membuat dokumen SK Mengajar.

5. Kaprodi melakukan koreksi terhadap SK Mengajar dan bersama dosen melakukan diskusi mengenai mata kuliah pilihan.

6. Sekretariat Fakultas mencetak dokumen SK Mengajar.

7. Dekan menandatangani dokumen SK Mengajar.

8. Sekretariat Fakultas membuat arsip dokumen SK Mengajar di komputer dan odner untuk setiap prodi.

Gambar 5. merupakan gambar proses pembuatan SK Mengajar yang lama dengan usulan yang telah dibuat.

\section{Kesimpulan}

Pada penelitian ini dilakukan perbaikan terhadap beberapa proses bisnis yang terdapat di Sekretariat Fakultas Sains dan Teknologi Universitas Ma Chung bagian layanan akademik. Perbaikan proses bisnis bertujuan untuk meminimalkan langkah kerja maupun elemen kerja yang termasuk kedalam business value adding dan menghilangkan langkah maupun elemen kerja yang termasuk kedalam non value adding. Perbaikan pada setiap proses bisnis juga bertujuan sebagai dasar pembuatan standard operating procedure, karena standard operating procedure yang terdapat di Sekretariat Fakultas tidak didokumentasikan dengan baik.

Perbaikan pada bagian layanan akademik dilakukan pada proses bisnis pembuatan SK mengajar, pembuatan jadwal perkuliahan, pembuatan jadwal UAS, persiapan UAS dan pasca UAS, pembuatan SK dosen PA, persiapan perkuliahan, pengajuan asisten dosen, pengajuan dosen LB dan pembuatan undangan rapat dan notulensi.

Perbaikan dilakukan dengan menggunakan pendekatan ilmu rekayasa proses bisnis. Tujuan dari penelitian ini adalah untuk menghilangkan atau mengganti setiap elemen kerja yang termasuk ke dalam non value adding dan meminimalkan elemen kerja yang termasuk ke dalam business value adding dengan menggunakan pendekatan ilmu rekayasa proses bisnis. Tabel 4. merupakan tabel hasil dari penelitian dengan menggunakan pendekatan ilmu rekayasa proses bisnis.

Tabel 4. Perbandingan Proses Pembuatan SK Mengajar Lama dan Usulan

\begin{tabular}{|c|c|c|c|c|c|c|}
\hline \multicolumn{3}{|c|}{ Aktivitas Pembuatan SK Mengajar yang Lama } & \multicolumn{4}{|c|}{ Aktivitas Pembuatan SK Mengajar Usulan } \\
\hline Langkah & Elemen kerja & Keterangan & Langkah & $\begin{array}{l}\text { Elemen } \\
\text { kerja }\end{array}$ & Keterangan & $\begin{array}{c}\text { Kategori } \\
\text { Elemen } \\
\text { Kerja Baru }\end{array}$ \\
\hline \multirow{2}{*}{ Pertama } & Pertama & $\begin{array}{l}\text { Kaprodi membuat } \\
\text { form untuk plotting } \\
\text { mata kuliah } \\
\text { semester berikutnya }\end{array}$ & \multirow{3}{*}{ Pertama } & Pertama & $\begin{array}{l}\text { Sekretariat Fakultas } \\
\text { membuat form } \\
\text { template usulan } \\
\text { berdasarkan kurikulum } \\
\text { setiap prodi }\end{array}$ & $\begin{array}{l}\text { Value } \\
\text { adding }\end{array}$ \\
\hline & Kedua & $\begin{array}{l}\text { Kaprodi } \\
\text { menyerahkan hasil } \\
\text { form rapat plotting } \\
\text { kepada Sekretariat } \\
\text { Fakultas }\end{array}$ & & Kedua & $\begin{array}{l}\text { Sekretariat } \\
\text { mengunggah form } \\
\text { template usulan rapat } \\
\text { plotting di sharing } \\
\text { folder }\end{array}$ & $\begin{array}{l}\text { Value } \\
\text { adding }\end{array}$ \\
\hline \multirow{5}{*}{ Kedua } & Pertama & $\begin{array}{l}\text { Sekretariat Fakultas } \\
\text { menerima dan } \\
\text { mengunduh form } \\
\text { hasil rapat plotting }\end{array}$ & & Ketiga & $\begin{array}{l}\text { Sekretariat Fakultas } \\
\text { mengumumkan } \\
\text { pelaksanaan rapat } \\
\text { plotting }\end{array}$ & $\begin{array}{l}\text { Value } \\
\text { adding }\end{array}$ \\
\hline & Kedua & $\begin{array}{l}\text { Sekretariat Fakultas } \\
\text { membuat dokumen } \\
\text { SK Mengajar }\end{array}$ & \multirow{4}{*}{ Kedua } & Pertama & $\begin{array}{l}\text { Kaprodi membuka } \\
\text { sharing folder }\end{array}$ & $\begin{array}{l}\text { Value } \\
\text { adding }\end{array}$ \\
\hline & Ketiga & $\begin{array}{l}\text { Sekretariat Fakultas } \\
\text { melakukan } \\
\text { verifikasi terhadap } \\
\text { dosen yang } \\
\text { bersangkutan }\end{array}$ & & Kedua & $\begin{array}{l}\text { Kaprodi mengisi form } \\
\text { usulan template rapat } \\
\text { plotting }\end{array}$ & $\begin{array}{l}\text { Value } \\
\text { adding }\end{array}$ \\
\hline & & & & & & $\begin{array}{l}\text { Value } \\
\text { adding }\end{array}$ \\
\hline & Keempat & $\begin{array}{l}\text { Sekretariat } \\
\text { mengirim dokumen } \\
\text { SK Mengajar }\end{array}$ & & Ketiga & $\begin{array}{l}\text { Kaprodi menyimpan } \\
\text { form usulan template } \\
\text { di sharing folder }\end{array}$ & \\
\hline
\end{tabular}




\begin{tabular}{|c|c|c|c|c|c|c|}
\hline \multicolumn{3}{|c|}{ Aktivitas Pembuatan SK Mengajar yang Lama } & \multicolumn{4}{|c|}{ Aktivitas Pembuatan SK Mengajar Usulan } \\
\hline Langkah & $\begin{array}{c}\text { Elemen } \\
\text { Kerja }\end{array}$ & Keterangan & Langkah & $\begin{array}{c}\text { Elemen } \\
\text { Kerja }\end{array}$ & Keterangan & $\begin{array}{c}\text { Kategori } \\
\text { Elemen } \\
\text { Kerja Baru } \\
\end{array}$ \\
\hline \multirow{3}{*}{ Ketiga } & Pertama & $\begin{array}{l}\text { Dosen menerima } \\
\text { dokumen SK } \\
\text { Mengajar }\end{array}$ & Ketiga & & $\begin{array}{l}\text { Dosen melakukan } \\
\text { sosialisasi kepada } \\
\text { mahasiswa mengenai } \\
\text { mata kuliah pilihan } \\
\text { yang dibuka }\end{array}$ & $\begin{array}{l}\text { Value } \\
\text { adding }\end{array}$ \\
\hline & Kedua & $\begin{array}{l}\text { Dosen melakukan } \\
\text { koreksi terhadap } \\
\text { SK Mengajar yang } \\
\text { dibuat }\end{array}$ & \multirow{3}{*}{ Keempat } & Pertama & $\begin{array}{l}\text { Sekretariat Fakultas } \\
\text { membuka sharing } \\
\text { folder }\end{array}$ & $\begin{array}{l}\text { Value } \\
\text { adding }\end{array}$ \\
\hline & Ketiga & $\begin{array}{l}\text { Sekretariat Fakultas } \\
\text { melakukan revisi } \\
\text { terhadap SK } \\
\text { Mengajar }\end{array}$ & & Kedua & $\begin{array}{l}\text { Sekretariat Fakultas } \\
\text { membuat SK Mengajar } \\
\text { berdasarkan form } \\
\text { usulan yang telah } \\
\text { standar }\end{array}$ & $\begin{array}{l}\text { Value } \\
\text { adding }\end{array}$ \\
\hline \multirow{3}{*}{ Keempat } & Pertama & $\begin{array}{l}\text { Sekretariat Fakultas } \\
\text { mencetak dokumen } \\
\text { SK Mengajar }\end{array}$ & & Ketiga & $\begin{array}{l}\text { Sekretariat Fakultas } \\
\text { mengunggah dokumen } \\
\text { SK Mengajar di } \\
\text { sharing folder }\end{array}$ & $\begin{array}{l}\text { Value } \\
\text { adding }\end{array}$ \\
\hline & Kedua & $\begin{array}{l}\text { Dekan menyetujui } \\
\text { SK Mengajar }\end{array}$ & \multirow{3}{*}{ Kelima } & Pertama & $\begin{array}{l}\text { Kaprodi bersama dosen } \\
\text { melakukan diskusi } \\
\text { mengenai mata kuliah } \\
\text { pilihan berdasarkan } \\
\text { daftar sementara } \\
\text { mahasiswa yang } \\
\text { mengambil mata kuliah } \\
\text { pilihan }\end{array}$ & $\begin{array}{l}\text { Value } \\
\text { adding }\end{array}$ \\
\hline & & & & Kedua & $\begin{array}{l}\text { Kaprodi melakukan } \\
\text { koreksi terhadap } \\
\text { dokumen SK Mengajar } \\
\text { di sharing folder }\end{array}$ & $\begin{array}{l}\text { Business } \\
\text { value adding }\end{array}$ \\
\hline \multirow{5}{*}{ Kelima } & Pertama & $\begin{array}{l}\text { Sekretariat Fakultas } \\
\text { membuat hasil scan } \\
\text { SK Mengajar }\end{array}$ & & Ketiga & $\begin{array}{l}\text { Sekretariat Fakultas } \\
\text { melakukan revisi } \\
\text { secara online (bila } \\
\text { diperlukan) }\end{array}$ & $\begin{array}{l}\text { Business } \\
\text { value adding }\end{array}$ \\
\hline & Kedua & $\begin{array}{l}\text { Sekretariat Fakultas } \\
\text { membuat arsip } \\
\text { dokumen SK } \\
\text { Mengajar di odner }\end{array}$ & Keenam & & $\begin{array}{l}\text { Sekretariat Fakultas } \\
\text { mencetak dokumen SK } \\
\text { Mengajar }\end{array}$ & $\begin{array}{l}\text { Value } \\
\text { adding }\end{array}$ \\
\hline & & & Ketujuh & & $\begin{array}{l}\text { Dekan menandatangani } \\
\text { dokumen SK Mengajar }\end{array}$ & $\begin{array}{l}\text { Value } \\
\text { adding }\end{array}$ \\
\hline & & & \multirow[b]{2}{*}{ Kedelapan } & Pertama & $\begin{array}{l}\text { Sekretariat Fakultas } \\
\text { membuat hasil rekapan } \\
\text { scan SK Mengajar }\end{array}$ & $\begin{array}{l}\text { Value } \\
\text { adding }\end{array}$ \\
\hline & & & & Kedua & $\begin{array}{l}\text { Sekretariat Fakultas } \\
\text { membuat arsip } \\
\text { dokumen SK Mengajar } \\
\text { di odner yang berbeda } \\
\text { untuk setiap prodi }\end{array}$ & $\begin{array}{l}\text { Value } \\
\text { adding }\end{array}$ \\
\hline
\end{tabular}




\section{Daftar Pustaka}

Dumas, M., Rosa, M. L., Mendling, J. dan Reijers, H. A. (2013) Fundamentals of Business Proces Management. New York: Springer.

Losee, R. M. (1997) 'A discipline Independent Definition of Information.' Journal of The American Society for Information, 48(3), pp. 254269.

Magal, S. R., dan Word, J. (2012) Integrated Business Process with ERP Systems. New Jersey: John Wiley \& Sons.
Singal, GL., dan Saluja, GP. (2014) Standard Operating Procedures and Regulatory Blood Banking. New Delhi: Jaypee Brothers Medical.

Sutabri, T. (2005) Sistem Informasi Manajemen. Yogyakarta: Andi Offset.

Wang, R. Y., dan Strong, D. M. (1996) 'Beyond Accuracy: What Data Quality Means to Data Consumers.' Journal of management information system, 12(4), pp. 5-33. 